London: H.M.S.O., $1952 ; 3 s .6 d$. net). It includes the text of the Minister's opening address, Sir George Schuster's address on the work of the Panel on Human Factors in Industry ; Sir Cuthbert Clegg and Mr. T. Williamson's comments on the work of the Anglo-American Council on Productivity; and reports of the discussions, together with the final text of the four group reports on, respectively, the opportunity to work, the capacity of workers, wastage of man-power and the will to work. Appended to the report are the papers on these subjects issued for discussion at the conference, and the paper summarizing the findings of the industrial productivity teams of the Anglo-American Council on Productivity relating to subjects on the agenda of the Conference ; also included is Sir George Schuster's memorandum on conclusions drawn from the projects sponsored by the Schuster Panel on Human Factors in Industry.

\section{Durban Museum and Art Gallery: Annual Report for $1950-51$}

ThE report of the Durban Museum and Art Gallery for $1950-51$ is the last issued under the directorship of Mr. E. C. Chubb, who has so ably controlled the remarkable progress of this institution for forty-one years. Occasion is thus taken in the report to review this long period, which is shown to be one of continuous growth accompanied by increased popularity and educational value, limited only during the past few years by restricted accommodation. Unfortunately, although a new building embodying more adequate accommodation has been advocated during the past fourteen years, circumstances resulting from the Second World War have prevented its realization.

\section{University College of North Staffordshire: Appoint- ments}

THE following appointments in the University College of North Staffordshire have recently been made : Senior Lecturer, Dr. A. M. Macbeath (mathematics) ; Lecturers, Dr. Monica M. Cole (geography), Miss Ruth M. Badcock and R. L. Plack (biology), Dr. D. J. O'Connor (philosophy), Mrs. P. Elizabeth Perrott (education), Dr. A. Fröhlich and B. Noble (mathematics), Dr. G. F. Smith (chemistry), and A. H. Oliffe (psychology); Assistant Lecturers, A. Hunter (economics), W. M. Williams (geography), Dr. S. C. Nyburg (chemistry), Miss Helga M. T. Frankland (biology), and P. H. Shelford and A. F. Trendall (geology).

\section{University of Birmingham : Appointments}

THE following appointments in the University of Birmingham have recently been announced: Lecturers, R. D. Mackey (civil engineering), K. M. Brown and W. G. Thomas (mining); Research Fellows, Dr. L. A. Radicati and Dr. J. G. Valatin (mathematical physics), J. J. Pick (Lucas Research Fellow in industrial metallurgy), and B. E. L. Deckker (James Watt Research Fellow in mechanical engineering).

British Society of Rheology: Members of Committee

AT the recent annual general meeting in Southampton of the British Society of Rheology, members of committee were elected as follows : President, A. G. Ward; Secretary, A. P. Feltham (British Iron and Steel Research Association, 140 Battersea Park Road, London, S.W.11) ; Treasurer, Dr. J. G. Oldroyd ; Editor, A. A. Milne; Northern Representative, L. Grunberg; Midland Representative, A. W. Richardson ; Ordinary Members, D. W. Jopling, Dr. J. W. S. Mardles and N. Wookey.

\section{Announcements}

THE autumn provincial meeting of the Physical Society will be held in the Physical Laboratories of the University of Manchester during December 18-19. The meeting will be on "Ionization Loss by Relativistic Particles" and will include speakers from the Atomic Energy Research Establishment, Harwell, and from the Universities of Bristol, Brussels, Glasgow, Leeds and Manchester. Non-members are welcome to attend. Details of the programme and application forms can be obtained from the Offices of the Society at 1 Lowther Gardens, Prince Consort Road, London, S.W.7.

To mark the opening earlier in the year of the Texile Institute's new headquarters at 10 Blackfriars Street, Manchester 3, a series of inaugural lectures is to be given there, the speakers and their subjects being as follows: October 24, Sir Ben Lockspeiser (secretary of the Department of Scientific and Industrial Research), on "Science in Industry" ; November 21, Sir Wallace Akers (a director of Imperial Chemical Industries, Ltd.), on "The Chemical Industry and Textiles"; and January 30, Mr. A. H. Wilson (research director of Courtaulds, Ltd.), on "Whither Man-Made Fibres ?". Each lecture will commence at 3 p.m. Admission is by ticket, applications for which should be made to the Registrar of the Institute at the above address.

The twelfth series of postgraduate lectures organized by the Oil and Colour Chemists' Association will be given by Prof. C. E. H. Bawn, professor of inorganic and physical chemistry in the University of Liverpool, who will speak on "Autoxidative Reactions: their Chemistry, Mechanisms and Catalysis by Metal Salts". The lectures will be given at 6.30 p.m. on November 17, 24 and December 12 in the Lecture Theatre of the London School of Hygiene and Tropical Medicine, Keppel Street, London, W.C.1. The fee for attendance is 15s. for members of the Association and $£ 1$ for others (inclusive of a copy of the lectures). Further information can be obtained from the Association at Memorial Hall, Farringdon Street, London, E.C.4.

The Medical Research Council invites applications for the Kathleen Schlesinger Fellowship, tenable initially for one year at the National Hospital for Diseases of the Nervous System, Queen Square, London, and worth $£ 700-1,000$ a year. This Fellowship is provided from a fund established by the late Mr. and Mrs. E. M. Schlesinger in memory of their daughter ; it is for the investigation of the origin and nature of eysts of the brain, and preference will be given to candidates who elect to work on the mechanisms underlying degenerative processes affecting the brain. Applications must reach the Secretary of the Medical Research Council, 38 Old Queen Street, London, S.W.1, not later than November 15.

THE University of Chicago, with the financial support of the Rockefeller Foundation, is offering three postdoctoral fellowships in statistics for 1953-54. These fellowships, which are worth 4,000 dollars each, are open to holders of a doctorate or its equivalent in research accomplishment, and their purpose is to enable research workers in the biological, physical and social sciences to acquire training for the application of statistical methods to their normal work. Details of application (to be completed by February 3, 1953) and further information can be obtained from the Committee on Statistics, University of Chicago, Chicago 37. 